\section{OP2-053 IPSSをより有効に活用する分析方法}

\section{米沢市立病院泌尿器科}

高岩 正至,小関 清夫

【目的】IPSS の有効活用【方法と対象】国際前立腺症状症 スコアーIPSS の質問項目で Q1 (残尿感)、Q2 (2 時間以 内の尿意）、Q3 (尿意急迫)、Q4 (夜間排尿) の 4 つは膀 胱刺激に関する、また Q3 (尿線中絶)、Q5 (尿の勢い)、 Q6 (腹圧排尿) は尿排出に関するアンケートである。膀 脱刺激症状の 4 つの質問事項の合計点数を満点 20 から 引いた数字を 20 で割り刺激満足率として\%表示した。同 様に尿排出症状の 3 つの質問事項の合計点数を満点 15 から引いた数字を 15 で割り排出満足率として、QOL ス コアを満点 6 から引いた数字を 6 で割り QOL 満足率と して\%表示した。対象は当科外来患者の男 69 名。調查機 関は 2003 年 3 月から 9 月まで。【結果】刺激满足率は平均 $64 \%$ 、排出满足率は平均 $69 \%$ 、QOL 满足率は平均 $30 \%$ であった。刺激満足率と排出満足率には負の相関（ $\mathrm{p}<$ $0.01 ）$ が、刺激満足率と QOL 満足率には正の相関（ $\mathrm{p}<$ 0.01）が、排出満足率と QOL 満足率には負の相関 $(\mathrm{p}<$ 0.05）があった。結語】IPSSの膀胱刺激と尿排出の項目 を別々に評洒し、百分率で数值化する本法は、医師、患 者双方にとって認知しやすい。本法は病状説明・状態把 握・治療法の選択などに有用と考える。また刺激、排出、 QOL 各満足率の関連性に、価値ある新知見を得た。

\section{OP2-054 前立腺肥大症症例における国際前立腺 症状スコア（IPSS）とその日常生活支 障度調查}

\footnotetext{
東京慈恵会医科大学"1, 国立西埼玉中央病院泌尿器

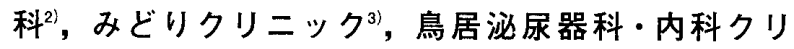
ニック ${ }^{4)}$ 新ゆり武内クリニック

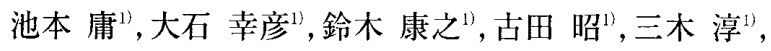

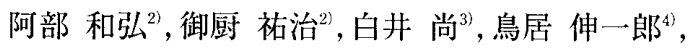
武内 宏之 ${ }^{5}$

【目的】前立腺肥大症 (BPH) 評価に拈ける影響指数 (BII) の項目のう ち、日常生活への支障度を尋权西項目が $\mathrm{BPH}$ の重症度 (程度) としての 質問項目の一つとなっていることに着目し，頻度調查である I-PSSの 7 項目に対方る日常生活への支障度を質問した.[方法]最近 1 年間に BPH と診断された 29 例に対し, I-PSS の各項目に対応する日常生活へ の7つの文障度調查表を作成し，8-12 週のナフトピジル(Naf) 治療前 後で I-PSS, QOL index, BII，本調查表を集計した１）投与開始前の IPSS と本調查表は, 7 項目ともに相関を示したが, Nafによる治療後では 類度と重症度では一致しない症状が認められた。2) Nafがどういう症例 に有効かを検討すると、NafによるQOL index の変化に影響を与える治 療前の項目は, I-PSSでは選ばれず, 本調查表では夜間頻尿の存在で あった。3) Nafがどういう症状に有効かを治療前後で検討すると, I-PSS では尿意切迫感と夜間頻尿の改善が, 本調査表では尿意切迫感の改善が 大きく寄与していることが示唆された。はとめ】排尿障害の主観的評 洒・解析には頻度のみならず程度の語価も必要であり，Nafでは刺激症 状の項目が QOL に大きな影響を与えているものと考兄られた。
}

OP2-055 排尿筋収縮障害いわゆる weak detrusor 発症に関する一考察一前立腺肥大 症患者での検討一

\begin{abstract}
福島県立医科大学
横田 崇, 細井 隆之, 塩見 誉, 柳田 知彦, 山口 脩 【目的】前立腺肥大症 (BPH) 患者の排沓障害は尿道閣塞によるもの ばかりでなく，排尿筋收縮障害いわゆる Weak Detrusor (WD) が 関与していることが判明した。この WD の原因として加秢や閉塞に よるものが考えられているがその病態は不明である。今回年齢, 閉 塞の程度とWDの頻度の関連索検討した。対象と方法】 BPH とし て乎術を受けた 50 例(51 84 歳)を対象とした。PFSは14Gカテー テルを恥骨上より膀胱に挿入し施行。膀腅機能とB00の程度は Schafer nomogram で判定した。年齢は 60 歳以下 (6 例), 61 70 歳 (25例), 71 歳以上 (19例) に, 閉塞の程度は 1 以下 (8 例), 2 3 (15 例)，4以上 (27 例) の各々 3 群に分類してWD の発生頻度に つき検討した。結果】WD の発生頻度は年齢別で各々 $3 / 6(50 \%)$, $9 / 25(36 \%), 8 / 19(42.1 \%)$ で, 閉塞の程度別では $6 / 8(75 \%), 10 /$ $15(66.7 \%) ， 4 / 27(14.8 \%)$ であった。年齢別による閉塞の程度は $2.3 \pm 1.6,3.4 \pm 1.63 .5 \pm 1.4$ と 60 歳以下で低值であった。閉塞の程度別 による平均年齢（歳）は $64.9 \pm 4.968 .4 \pm 6.3,68.9 \pm 6.5$ と徐々に高く なった。[考察]WDの頻度は閉塞の程度が弱い程, 年齢が若い程高 い傾向にあった。一方閉塞が強い症例にWDの頻度が低かった。 れは加齢に伴い前立腺が腫大し閉塞が增強して排尿障害が增える $\mathrm{BPH}$ の病態とは異なる結果であった。即ち, WD の発症には加齢や 閉塞とは関係ない何加別な要因が示唆される。
\end{abstract}

\section{OP2-056 Chlormadinone acetate 投与による前 立腺肥大症患者の PSA 值の変動：多 施設共同自主研究}

\section{CMA-PSA 研究会}

藤本 清秀, 塚本 泰司, 多森 直哉, 荒井 陽一, 高橋 公太, 山中 英寿, 赤座 英之, 石井 延久, 加藤 聡彦, 鈴木 孝治, 宮澤 克人, 大島 伸一, 平尾 佳彦

【目的】前立腺肥大症 (BPH) 患者への抗アンドロゲン剤 (AA 剂) 投与 は、血清PSA 值を低下させ潜在する前立腺癌の診断に影響を与える可能 性があるため、酢酸クロルマジノン (CMA) 投与によるPSA 值の変動を 検討した。対象】臨床的にBPH と診断され、CMA $50 \mathrm{mg} /$ 日を投与された 症例で、投与前 PSA 值が $20 \mathrm{ng} / \mathrm{ml}$ 未渵であった 166 例を retrospective に解析した。共同研究参加施設は、札幌医科大学、東北大学、新潟大学、 群馬大学、筑波大学、東邦大学、金沢医科大学、名古屋大学、奈良県立医 科大学。【結果】 CMAの平均投与期間は $96.4 \pm 76.6$ 週（中央值：76.1）。 $\mathrm{CMA}$ 投与前平均 PSA 值は $4.47 \pm 4.20 \mathrm{ng} / \mathrm{ml}$ で、投与 16 週で $1.98 \pm 2.62$ と有意に低下した。投与前 PSA 值が $4.0 \mathrm{ng} / \mathrm{ml}$ 末満の 101 例での投与前 平均PSA 值は $1.89 \pm 1.05$ で、投与 $16 、 26.52$ 週での值は $0.61 \pm 0.36 、 1.39 \pm$ $1.05 .0 .86 \pm 0.63$ と有意に低下した。PSA 值の推移を非線形回㷌分析した 結果、投与前 PSA 值を 100 とした変化率（全例/PSA<4.0 例）は、16 週：-49.9/-43.5、26 週：-49.9/-44.2、52 週：-49.9/-44.3 と 約 50/44\%の 低下であった。CMA 投与中に前立腺癌が診断された症例は 1 例のみで、 前立腺癌の診断に関する CMA 投与の影響に関する結論岷得られなかっ た。結語】 CMA 投与により BPH 患者のPSA 值は有意に低下すること から、投与後も定期的な前立腺癌スクリーニングの実施が望まれる。 